\title{
Nutritional Status of Preschools Children and its Effect on the Intelligent Quotient
}

\author{
By \\ Mona S. El-Kutry \\ Home Economics Dept., Faculty of Education, Ain shams Univ., Cairo Egypt
}

\section{$\underline{\text { Abstract: }}$}

The present work aimed to evaluate the nutrition status of 120 children (70 boys $\& 50$ girls), in preschool age and its effects on the intelligent score. Results indicated that $69 \%$ of the children were in healthy weight; however $10.8 \%$ of them had over weight and $20 \%$ were obese. Concerning the intake of fat and carbohydrate, it has been noticed that children had high percentage of RDA it reached $138.9 \%$ and $111.8 \%$, respectively. Results indicated that the intake of antioxidant, vitamin $\mathrm{C}, \mathrm{A}$ and $\mathrm{E}$ for children were lower than RDA by 39.2, 34.6 and $79.9 \%$, respectively. Food habits of children indicated that $70 \%$ of them don't eat fresh vegetables or fruits per day. Also, about $65 \%$ of the children have drunk the soda beverage or/and tea equal or more than twice per day. Data indicated that there was significant negative correlation between IQ and BMI percentile. Mean while, there was statistical significant positive correlation between vitamin $\mathrm{A}$ and IQ at $\mathrm{P} \leq 0.01$. Finaly, it is recommended kids that should increase consumption of the fresh vegetables, fruits and instead of the soft drinks consume by fresh juices. Also, less fats and added sugars should be considered.

Key words: Nutrition status - Children- Antioxidant- BMI percentile- Intelligent Quotient.

\section{Introduction}

In the developing countries, many population groups suffer from multiple micronutrient deficiencies, iron and vitamin A, are the ones most commonly reported Unicef, (2009). Infants are likely to have multiple, concurrent deficiencies, because the same causative factors are responsible for deficiency 
of different micronutrients. It has been stated that the cereal-based diets commonly consumed in developing countries are rich in phytate and low in animal products, predisposing people to insufficient absorption of both iron and zinc and low intakes of several vitamins (Ferguson,et al., 1993) .

Food and Agriculture Organization (FAO), 2003 reported that anaemia is considered to be a moderate public health problem in Egypt. Also, vitamin A deficiency among preschoolers and their mothers is considered to be subclinical, mild-to-moderate, public health problem, habits start being formed at the age of 3-4 years. Adequate intakes of iron, vitamin A, zinc, iodine, and other micronutrients are essential for growth, as well as mental and motor development, and for the prevention of disease (Bourre, 2006). Children with micronutrient deficiencies often present with linear growth retardation, higher morbidity and mortality, and reduced psychomotor development, and those who survive have less possibility of developing to their full potential, Kikafunda, et al., (1998) and Vazir, et al., (1998) .

Ogden et al., (2010) found that obesity is prevalent among U.S. children from infancy through adolescence. Children from birth to 2 years of age had high weight-for-length $\left(>95^{\text {th }}\right.$ percentile). Number of studies provided evidence that childhood obesity (defined by BMI > 95th percentile) is associated with certain chronic diseases and conditions. These diseases include, type 2 diabetes (Weiss and Caprio, 2005; Messiah et al., 2008), hypertension (Jago et al., 2006), and metabolic syndrome (De Ferranti et al., 2006) .

Reports of Earlier IOM, (2010) on childhood obesity associated to metabolic syndrome, cardiovascular disease. Overweight children had significantly lower math and reading test scores compared with non-overweight children in kindergarten Ashlesha, (2004) .

$\mathrm{Li}$, (1995) used data on primary school children in China and found that severely obese children had significantly lower IQ (intelligence quotient) scores than the controls. It is therefore important to evaluate nutrition status of preschool age children and its effect on intelligent quotient score. 


\section{Subjects and methods:}

Subjects: One hundred twenty healthy child were randomly 70 boys $\& 50$ girls at age from three to six years (pre-school children) were selected from kindergartner schools in Cairo- Egypt

Evaluation of Nutrition statues: $24-\mathrm{h}$ recall was used to determine food intake using 24 hour recall method for three following days, mothers were asked to recall food and beverage consumed by each child in the past 24 hour using household measurements such as cup, spoon, and approximate size. Then, all food items were analyzed using nutrition software system (USDA, 2010) national nutrient database for standard reference -Release 22. This system translates the amounts of eaten food into individual nutrients. Mean intake values were compared with the Recommended Dietary Allowances (RDA) National Academy of Sciences ,2004) .The daily intake of each nutrition was calculated to estimate the dietary intake of protein, fat, carbohydrate, fiber, calcium, iron, zinc, selenium, choliene, biotin , vitamin C, vitamin A and vitamin E.

Questionnaire : A questionnaire was administrated to mothers of children included name, sex, age, allergy of some food, drug intake or dietary supplement, fast food (chips) intake, fresh fruit, vegetable and black tea or soft drink consumed.

Anthropometric Measurements: Children were weighed by lightly dressed and barefoot .Height was measured to the nearest mill meter and weight to the nearest 0.1 KG using standardized electronic digital scales. These measurements were then used to calculate the body mass index (BMI) by dividing weight in $(\mathrm{kg})$ by height in meters square $\left(\mathrm{kg} / \mathrm{m}^{2}\right)$. BMI percentiles chart. It works for all ages (2-20 years). 1 th $-4^{\text {th }}$ percentile is considered under weight, $5-85^{\text {th }}$ was healthy weight, $85-94^{\text {th }}$ is considered over weight and 95$100^{\text {th }}$ became Obesity (Center for Diseases control National center for health statistics, 2000). 
Table (1) Classification of the Children According to Body Mass Index (BMI) Percentiles* .

\begin{tabular}{|c|c|c|c|}
\hline \multicolumn{3}{|r|}{ Variables } & \multirow{2}{*}{$\begin{array}{r}\text { Values } \\
4.8 \pm 0.8\end{array}$} \\
\hline Age & $(\mathbf{y})$ & Mean \pm SD & \\
\hline \multirow{4}{*}{\multicolumn{2}{|c|}{ 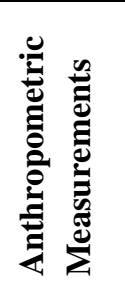 }} & Weight (Kg) Mean \pm SD & 18.004 .4 \\
\hline & & Height $(\mathrm{cm})$ Mean \pm SD & $1.04 \pm 0.09$ \\
\hline & & BMI $\left(\mathrm{Kg} / \mathrm{M}^{2}\right)$ Mean \pm SD & $16.8 \pm 3.5$ \\
\hline & & BMI percentiles Mean \pm SD & $56 \pm 34$ \\
\hline \multirow{3}{*}{ 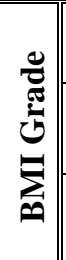 } & $\begin{array}{l}\infty \\
\infty \\
i \infty \\
i n j\end{array}$ & $\begin{array}{l}\text { (Healthy weight ) } \\
\mathrm{n}=83\end{array}$ & $69.2 \% * *$ \\
\hline & $\begin{array}{l}10 \\
\hat{1} \\
\dot{0} \\
\Lambda 1\end{array}$ & $\begin{array}{l}\text { (Over weight ) } \\
\mathrm{n}=13\end{array}$ & $10.8 \%$ \\
\hline & $\stackrel{2}{\Lambda}$ & $\begin{array}{l}\text { (Obesity) } \\
\mathrm{n}=24\end{array}$ & $20 \%$ \\
\hline
\end{tabular}

* BMI for age percentiles chart $\quad * *$ Total sample equal 120 children

The Intelligence Quotient (IQ) The Stanford-Binet Intelligence Scale was originally developed to help place children in appropriate educational settings. It can help to determine the level of intellectual and cognitive functioning in preschool age and was translated by Mohamed \& Loues, (1980). It was administered to measure individually intelligence and cognitive abilities. Fluid reasoning, knowledge, quantitative reasoning, visual-spatial processing and working memory. The time of test application was 30 minutes. The test consists of 15 subtests, which are grouped into the four area scores. Not all subtests are administered to each age group; but six subtests are administered to all age levels. These subtests are: vocabulary, comprehension, pattern analysis, quantitative, bead 
memory, and memory for sentences. The number of tests administered and general test difficulty is adjusted based on the test taker's age and performance on the sub-test that measures word knowledge. The subtest measuring word knowledge is given to all test takers and is the first subtest administered. Scores were ranked as: mental retardation (IQ <70), borderline (IQ 70-79), dull normal (IQ 80-89), normal (IQ 90-109), bright normal (IQ 110-119), superior (IQ 120-129), and very superior (IQ >129).

\section{Statistical Analysis:}

The obtained data was analyzed using the Computer Statistical Package for Social Science Program (S.P.S.S). All results were represented as mean \pm standard deviation .Pearson's correlation coefficient (r) has also applied in this study to show the relationships between variables. A significant P-value was considered when $P$ is less than or equal $0.05(p \leq 0.05)$.T- test was used to show the significant differences between nutrition intake and IQ scores of the boys and girls. (SPSS, 1990)

\section{$\underline{\text { Results }}$}

Subject characteristics: The mean and standard deviation for age is listed in table (1). Data showed that a total number of 120 subjects ( 70 boys $\& 50$ girls) completed the study.Their age ranged from 3 - 6 years old with a mean ages of $4.8 \pm 0.8$ years.

Anthropometric Assessment: Results in table (1) exhibits classification of the children according to body mass index (BMI) percentiles. Data indicated, that (BMI) percentiles means were $\quad\left(56 \pm 34^{\text {th }}\right)$. Regarding health status of children the data showed $69 \%$ of children have healthy weight (BMI was 5-85 th ) However, $10.8 \%$ of children were overweight (BMI was $85-94^{\text {th }}$ ) and $20 \%$ of the subjects had obesity (BMI $\geq 95$ ). 
Nutrition Status: The mean and standard deviation for some nutrients compared with the RDA are listed in table (2).It presents nutrients compared to the recommended dietary allowance (RDA). Regarding protein intake it is clear that all tested children had low percentage of the RDA less than $100 \%$ of RDA by $65 \%$. Concerning fat intake it is noticed that children had high percentage of RDA compared with the RDA with a percentage of by138.9.

Children intake of carbohydrate was high, also by it represented $111.8 \%$ of the RDA. As regards, fiber it was clear that children had low percentage $20.5 \%$ of RDA. It was also obvious that children had low amount of calcium and iron with a mean of $60.3 \& 69.6 \%$ of the RDA, respectively. On the other hand the intake of Phosphorus by children was $128.6 \%$ of the RDA.

Table (2) Nutrients Intake Percentage Compared with RDA.

\begin{tabular}{|c|c|c|c|}
\hline \multicolumn{2}{|c|}{ Food Intake } & \multirow{2}{*}{$\begin{array}{c}\text { RDA \% } \\
65\end{array}$} & \multirow{2}{*}{$\begin{array}{r}\text { Mean } \pm \text { SD } \\
84.3 \pm 38.3\end{array}$} \\
\hline \multirow{4}{*}{ 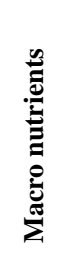 } & Protein (g/day) & & \\
\hline & Fats (g/day) & $138.9 *$ & $39.7 * \pm 14.6$ \\
\hline & $\begin{array}{c}\text { Carbohydrates } \\
\text { (g/day) }\end{array}$ & 111.8 & $145.3 \pm 63.6$ \\
\hline & Fiber (g/day) & 20.5 & $5.1 \pm 5.9$ \\
\hline \multirow{7}{*}{ 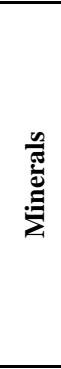 } & Calcium (mg) & 60.3 & $482.3 \pm 199.6$ \\
\hline & Iron (mg) & 69.6 & $7.0 \pm 2.8$ \\
\hline & Phosphorus(mg) & 128.6 & $643.0 \pm 292.8$ \\
\hline & Zinc (mg) & 129.6 & $6.48 \pm 5.24$ \\
\hline & Selenium $(\mu \mathrm{g})$ & 175.3 & $52.6 \pm 23.3$ \\
\hline & Choliene (mg) & 25.5 & $63.8 \pm 44.4$ \\
\hline & Biotin (mg) & 26.8 & $3.22 \pm 6.24$ \\
\hline \multirow{3}{*}{ 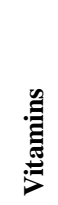 } & Vitamin C (mg) & 39.2 & $9.8 \pm 9.8$ \\
\hline & Vitamin A (IU) & 34.6 & $461.5 \pm 249.2$ \\
\hline & Vitamin E (mg) & 78.9 & $5.5 \pm 12.4$ \\
\hline
\end{tabular}

$*$ Values are significantly differed at $\mathrm{p} \leq 0.05$ 
Antioxidants intake by children : The mean and standard deviation for of antioxidants were listed in table (2). A represents percentage of antioxidant intake as compared with the recommended dietary allowances (RDA). Intake of vitamin $\mathrm{C}, \mathrm{A}$ and $\mathrm{E}$ for children were lowest of RDA it represent 39.2, 34.6 and $79.9 \%$, respectively

Also, the consumption of choline and biotin were very low in samples of children it represent $25.5 \& 26.8 \%$ of RDA, respectively. Selenium was more sufficient for tested children presenting as it represent $175.3 \%$ of RDA. In addition of that the zinc intake by children was high, the percentage reached $129.6 \%$ of RDA.

\section{Evaluation the food habits of preschool children}

Table (3), represent evaluation of the food habits of preschool children .The data indicated that $70 \%$ of total sample don't consume fresh vegetables or fruits per day, only $35 \%$ of children eat fresh vegetables or fruits per day. Data shows that $35 \%$ of children eat chips more than once per day and $15 \%$ of them eat it more than twice per day. Children food habits shows that from the present data $45 \%$ of the sample drink soda drinks or/and tea more than once per day . As seen about $65 \%$ of children drink the soda beverage or/and tea more than twice per day.

\section{Classification the children according to Intelligence Quotient scale.}

Data in figure (1) shows that $21.6 \%$ of children got $100-110$ score in IQ test. Also the most percentage of children (37.5\%) had 100 score, but $29.20 \%$ of them had IQ score less than 95-100. The lowest percentage of children (11.7\%) had less than 86-95- IQ score.

The relationship between intelligent score, food intake and body mass index percentiles.

As seen from table (4) no significant relationship was found between IQ and any nutrients except vitamin $\mathrm{A}$. There was a statistical significant positive correlation between vitamin $\mathrm{A}$ and IQ at $\mathrm{P}<0.01$. Also, the data indicated that 
there was statistical significant negative correlation between IQ and BMI Percentile. As for the differences between boys and girls, results indicate there is no significant differences between IQ for boys and girls.

\section{$\underline{\text { Discussion }}$}

The present study was carried out to reveal relationship between the healthy and nutrition status of children, and their I Q score. This study observed that $69.2 \%$ of tested children showed a healthy weight. But also third of children showed overweight or obesity. This finding was an agreement with finding of (Ogden et al., 2010) that showed that the obesity is prevalent among U.S. children from infancy through adolescence.

Similar results were observed by Martorell et al., (2000) that showed the levels of obesity in preschool age of Egypt was $7.5 \%$ and overweight was found in over $20 \%$. The prevalent of obesity and overweight in preschool age in the studied sample was corresponding with the nutrition statues results that indicated that children consumed high amounts of fat (138.9\% of RDA) and the average intake of carbohydrate reached $111.8 \%$ of RDA. In addition, evaluation of children is food habits revealed that children consume high amounts of fast foods as ships where $35 \%$ of children eat the chips more than once per day and $15 \%$ of them eat it more than twice per day. This finding is in agreement with the finding by (Eaton et al., 2006) \& (Wang \& Lobstein, 2006). The percentage of youths who are at risk of becoming overweight continued to increase, and by the year 2010, it is expected that the number of overweight children will increase significantly worldwide, with almost $50 \%$ of children in North America and $38 \%$ of children in the European Union becoming overweight (Eaton et al., 2006).

Table (3): Food Habits Evaluation of the Tested Subjects. 


\begin{tabular}{|c|c|c|c|}
\hline \multicolumn{2}{|r|}{ Variables } & \multirow{2}{*}{$\begin{array}{l}\text { NO* } \\
84\end{array}$} & \multirow{2}{*}{$\begin{array}{c}\text { Percentage } \\
\% \\
70\end{array}$} \\
\hline 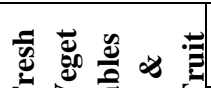 & $\begin{array}{l}\text { Children don't eat fresh veg. or } \\
\text { fruit/ day }\end{array}$ & & \\
\hline$E>\bar{\sigma}$ & Children eat fresh veg. or fruit /day & 42 & 35 \\
\hline \multirow{2}{*}{ 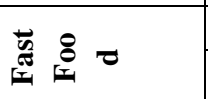 } & Children eat chips $>1 /$ day & 42 & 35 \\
\hline & Children eat chips $>2$ /day & 18 & 15 \\
\hline \multirow{2}{*}{ 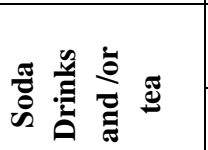 } & Children drink Soda or tea $>1 /$ day & 54 & 45 \\
\hline & Children drink Soda or tea $>2$ / day & 78 & 65 \\
\hline
\end{tabular}

*Total sample

equal $\quad 120$ children

Regarding the consumptio $\mathrm{n} \quad$ of antioxidant

by children results indicated that children consumed low amount of vitamins $\mathrm{C}$, $\mathrm{A}$ and $\mathrm{E}$. These finding is in agree with the results of $70 \%$ of total children don't eat fresh vegetables or fruits per day. However, selenium was more sufficient for the studied children presenting $175.3 \%$ of RDA. An addition zinc intake was high reaching $129.6 \%$ of RDA.

A wide variety of foods contain zinc. Red meat and poultry provide the majority of zinc in the American diet. Other good food sources include beans, nuts, certain types of seafood, whole grains, fortified breakfast cereals, and dairy products (Sandstrom, 1997). Whole-grain bread, cereals, legumes, and other foods contain phytates that bind zinc which inhibit its absorption. Thus, the bioavailability of zinc from grains and plant foods is lower than that from animal origin, although many grain- and plant-based foods are still rich sources of zinc (Wise, 2002).

Regarding iron and calcium, results indicated that children consumed low amounts of calcium and iron ( $60.3 \& 69.6 \%$ of RDA, respectively). So dietary habits start being formed at the age of 3-4 years, and tend to become very resistant to change form the age of 11years on wards Dunn, et al., (2000).

Table (4): The Correlation between IQ, Food intake (g) and Body Mass index (MBI) percentiles.

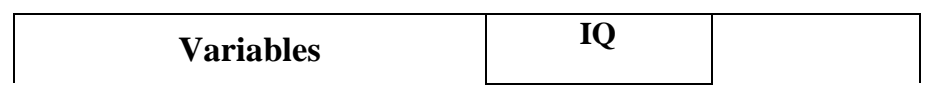




\begin{tabular}{|c|c|c|c|}
\hline & & $\begin{array}{c}\text { Pearson } \\
\text { Correlation }\end{array}$ & Significancy \\
\hline \multirow{5}{*}{ 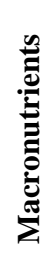 } & kcal & 0.012 & NS \\
\hline & Protein (g/day) & 0.017 & NS \\
\hline & Fat (g/day) & 0.079 & NS \\
\hline & $\begin{array}{l}\text { Carbohydrate } \\
\text { (g/day) }\end{array}$ & 0.001 & NS \\
\hline & Fiber (g/day) & 0.126 & NS \\
\hline \multirow{7}{*}{ 电 } & Calcium (mg) & 0.131 & NS \\
\hline & Iron (mg) & 0.119 & NS \\
\hline & Phosphorus (mg) & 0.057 & NS \\
\hline & Zinc (mg) & 0.173 & NS \\
\hline & $\begin{array}{l}\text { Selenium } \\
(\mu \mathrm{g})\end{array}$ & 0.040 & NS \\
\hline & Choliene (mg) & -0.055 & NS \\
\hline & Biotin (mg) & 0.009 & NS \\
\hline \multirow{3}{*}{ } & Vitamin C (mg) & 0.167 & NS \\
\hline & Vitamin A (IU) & 0.287 & $\mathrm{~S}^{*}$ \\
\hline & Vitamin E (mg) & 0.124 & NS \\
\hline \multicolumn{2}{|c|}{ AGE } & -0.044 & NS \\
\hline \multicolumn{2}{|c|}{ BMI percentiles } & -0.363 & $\mathrm{~S} * *$ \\
\hline
\end{tabular}

$\mathrm{S}^{*}=$ significancy at $\mathrm{P} \leq 0.001 \quad \mathrm{~S} * *=$ significancy at $\mathrm{P} \leq 0.0001$

These finding were in accordance with our results. Concerning result of children food habits as shows that $45 \%$ of samples have drunk the soda drinks more than once per day. As seen about $65 \%$ of children have drunk the soda beverage more than twice per day. These results were responsible for the increase the percentage of children had the overweight and obesity $(10.8 \%$ of children had over weight and $20 \%$ of subject had obesity). Our findings agreed with those of Malik, et al., (2006), who found linked between soft drinks with childhood obesity and $31 \%$ of children greater likelihood of becoming obese. Fowler, et al., (2008) noticed that heavy consumption of soft drinks can interfere with one body's metabolization of iron and diminish nerve impulse transmission. 
Cola drinks can interact adversely with antacids, possibly causing constipation, calcium loss, hypertension, nausea, vomiting, headaches, and kidney damage. An addition, Beverage Digest (2008) and Vartanian et al., (2007), found that soft drinks also contain large quantities of phosphorus, which when excreted pulls calcium out of the bones will cause an osteoporosis symptoms along with their damaged arteries.

Concerning the intelligent quotient the tested sample shows normal children and did not find any cases of mental retardation.As for the relationship between IQ and BMI percentiles, results shows that there was statistical significant negative correlation between IQ and BMI Percentile .This finding agreed with Chandola , et al., (2006) who found, that a lower IQ score in childhood is associated with obesity and weight gain in adulthood. Also, Olsson \& Hulting (2010) found that obese children are at increased risk of having below average IQ and strategies to tackle associated problems should be developed in paediatric obesity clinics. In general there was an inverse relationship between IQ and obesity, except in pre-school children. However, after adjusting for educational attainment, relationship between IQ and obesity was not significantly different. A lower IQ in childhood was associated with obesity in later adulthood perhaps with educational level mediating the persistence of obesity in later life Yu, et al., (2010).

Regarding the relationship between IQ and food intake. There was a significant positive correlation only between vitamin A and IQ $(\mathrm{P}<0.01)$ however, other nutrients showed statistical significant negative correlation between them and IQ. This finding were in a agree with that of Bourre, (2006) who, reported that food can have an influence on brain structure, and thus on its function, including cognitive and intellectuals. In spite of the brain is elaborated from substances present in the diet (sometimes exclusively, for vitamins, minerals, essential amino-acids and essential fatty acids). Also, Schoenthaler et al.,(2000), found that vitamin-mineral supplementation markedly increased the non-verbal intelligence of a minority of Western schoolchildren, presumably because they were too poorly nourished before supplementation for optimal 
brain function. So, nonverbal intelligence is closely associated with academic performance.

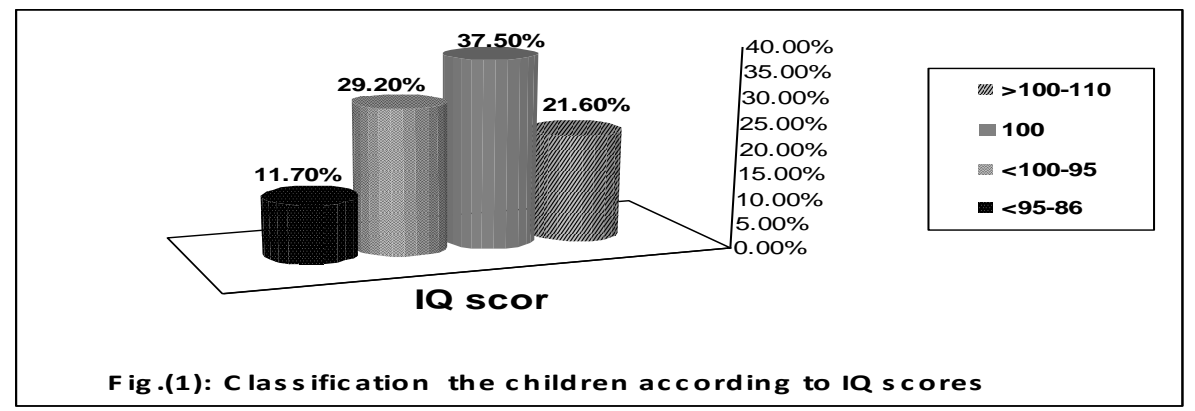

Whalley et al., (2002) found that dietary supplement users did not differ from dietary supplement non-users in years of education. Dietary supplement users had higher $(p<0.05)$ childhood IQ scores but did not differ in current Mini-Mental State Examination score or performance.

\section{Conclusion}

According to the obtained results should be focused on dietary consumption by preschool children .Encourage them increasing consumption of fresh vegetables and fruits, fresh juices, as well as decreasing the content of solid fats and added sugars. Preparing Nutrition education programs forward to parents, teachers and kids. Providing children by physical activity practices to reduce the risk of becoming overweight or obese.

\section{References}

- Ashlesha, Datar. (2004): Childhood Overweight and Academic -Performance: National Study of Kindergartners and First-Graders obesity research Vol. 12 No. 1 January 2004.

- Beverage Digest Fact Book (2008): Statistical Yearbook of Non-Alcoholic Beverages. Bedford Hills, New York. 
. Bourre, J.M. (2006): Effects of nutrients in food on the structure and function of the nervous system: update on dietary requirements for brain. Part 1: micronutrients. J Nutr Health Aging. 2006 Sep-Oct; 10(5):377-85.

. Center for Diseases Control National Center for Health Statistics, (2000): Body mass index (BMI) for age percentiles boys \& girls charts.

.Chandola, T., Deary, I.J., Blane, D. and Batty, G.D. (2006): Childhood IQ in relation to obesity and weight gain in adult life: the National Child Development. Int J. Obes (Lond).Sep; 30(9):1422-32.

.De Ferranti, S. D., Gauvreau, K., Ludwig, D. S., Newburger, J. W. and Rifai, N. (2006): Inflammation and changes in metabolic syndrome abnormalities in US adolescents: Findings from the 1988-1994 and 1999-2000 National Health and Nutrition Examination Surveys. Clinical Chemistry 52(7):1325-1330.

.Dunn, J.E., Liu, K., Greenland, P.h., Hilner, J.E.,Jacobs, D.R.(2000):Even years tracking of dietary factors in young adults .Am J. Prev Med 2000 18:38-45.

.Eaton, D. K., Kann, L., Kinchen, S., Ross, J., Hawkins, J. and Harris, W. A. (2006): Youth risk behavior surveillance-United States, 2005. Morbidity \& Mortality Weekly Report, 55(SS-5), 1-108.

. FAO, (2003): Food and Agriculture Organization of the United Nations Nutrition Country Profiles - EGYPT August, Rome, Italy.

. Ferguson, E. L., Gibson, R. S., Opare-Obisaw, C., Ounpuu, S., Thomson,L. U. and Lehrfeld, J. (1993): The zinc nutriture of preschool children living in two African countries. J. Nutr. 123: 1487-1496.

. Fowler, S.P., Williams, K., Resendez, R.G., Hunt, K.J., Hazuda, H.P. and Stern, M.P. (2008): Fueling the obesity epidemic? Artificially sweetened beverage use and long-term weight gain. Obesity (Silver Spring). 16:1894-1900.

. IOM (2010): Institute of Medicine. School Meals. Building Blocks for Healthy Children. Washington, DC: The National Academies Press.

. Jago, R., Harrell, J. S. R., McMurray, G. S., Edelstein, L., El Ghormli, D. and Bassin, S. (2006): Prevalence of abnormal lipid and blood pressure values among an ethnically 
diverse population of eighth-grade adolescents and screening implications. Pediatrics 117(6):2065-2073.

. Kikafunda, J. K., Walker, A. F., Collett, D. and Tumwine, J. K. (1998): Risk factors for early childhood malnutrition in Uganda. Pediatrics 102: E45.

. Li, X. (1995): A study of intelligence and personality in children with simple obesity. Int J. Obes. 19:355-7.

. Malik, V.S., Schulze, M.B. and Hu, F.B. (2006): Intake of sugar-sweetened beverages and weight gain: a systematic review. American Journal of Clinical Nutrition. 84:274-288.

. Martorell, R., Kettel, Khan. L., Hughes, M.L. and Grummer-Strawn, L.M. (2000): Overweight and obesity in preschool children from developing countries International Journal of Obesity. 24, $959 \pm 967$.

.Messiah, S. E., Arheart, K. L., Luke, B., Lipshultz, S. E. and Miller, T. L. (2008): Relationship between body mass index and metabolic syndrome risk factors among U.S. 8- to 14-year-olds, 1999 to 2002. Journal of Pediatrics 153(2):215-221.

.Mohamed, Abd Elsalam Ahamed and Loues, Kamel Melka. (1980): Stanford-Binet Intelligence Scale -Edition Eltaulef, translator and publication.

. National Academy of Sciences, (2004): Institute of Medicine. Food and Nutrition Board. Recommended Dietary Allowances (RDA).

.Ogden, C. L., Carroll, M. D., Curtin, L. R., Lamb, M. M. and Flegal, K. M. (2010): Prevalence of high body -mass index in US children and adolescents, 2007-2008. Journal of the American Medical Association 303(3):242-249.

.Olsson, G.M. and Hulting, A.L. (2010): Intellectual profile and level of IQ among a clinical group of obese children and adolescents. Eat Weight Disord. Mar-Jun;15(12):e68-73.

.Sandstrom, B. (1997): Bioavailability of zinc. Eur J Clin Nutr. 51 (1 Suppl):S17-9. PubMed Abstract.

.Schoenthaler, S.J., Bier, I.D., Young, K., Nichols, D. and Jansenns, S.(2000) : The effect of vitamin-mineral supplementation on the intelligence of American 
schoolchildren: a randomized, double-blind placebo-controlled trial. J Altern Complement Med. Feb;6(1):19-29.

. SPSS (1990): Statistical Package for Social Science releases 4, spss. Inc. Chicago.

. Unicef (2009): The state of the world children, pp. 5 and 51.

. USDA (2010): U.S. Department of Agriculture Nutrient Data Laboratory and healthy teach Inc. /USDA national nutrient database for standard reference by windows, version 1.0 database version SR22.

. Vartanian, L.R., Schwartz, M.B. and Brownell, K.D. (2007): Effects of soft drink consumption on nutrition and health: a systematic review and meta-analysis. American Journal of Public Health. 97:667-675.

. Vazir, S., Naidu, A. N. and Vidyasagar, P. (1998): Nutritional status,psychosocial development and the home environment of Indian rural children.Indian Pediatr. 35: 959-966.

. Wang, Y. and Lobstein, T. (2006): Worldwide trends in childhood overweight and obesity. International Journal of Pediatric Obesity, 1, 11-25.

.Weiss, R. and Caprio, S. (2005): The metabolic consequences of childhood obesity. Best Practice and Research: Clinical Endocrinology and Metabolism 19(3):405-419.

. Whalleym, L.J., Fox, H.C., Lemmon, H.A., Duthie, S.J., Collins, A.R., Peace, H., Starr, J.M. and Deary, I.J.(2003): Dietary supplement use in old age: associations with childhood IQ, current cognition and health - International Journal of Geriatric Psychiatry- Volume 18, Issue 9, pages 769-776.

.Wise, A. (2002): Phytate and zinc bioavailability. Int J Food Sci Nutr; 46:53-63.

.Yu, Z.B., Han, S.P., Cao, X.G. and Guo, X.R. (2010): Intelligence in relation to obesity: a systematic review and meta-analysis - Obes Rev. Sep; 11(9):656-70.

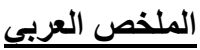




\section{الحالة الغذائية لأطفال في سن ما قبل المدرسه وتأثيرها علي معامل الأكاء \\ مني سعيد محمد القطري}

قسم الاقتصاد المنزلي- كليه التربية- جامعة عين شمس- جمهوريه مصر العربيه . .

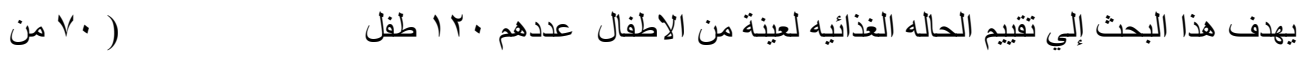

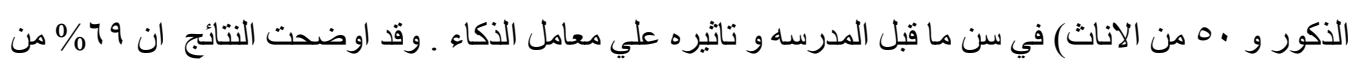

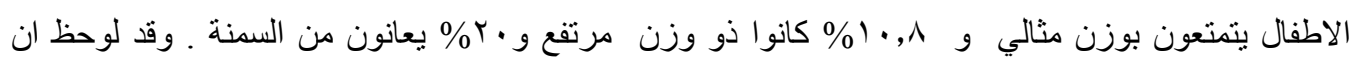

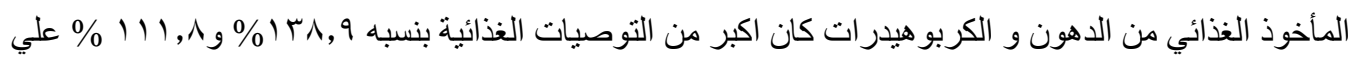

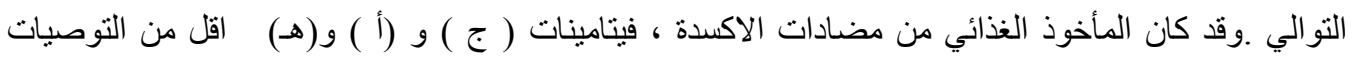

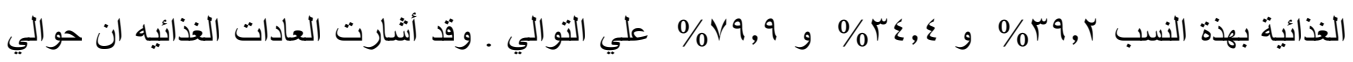

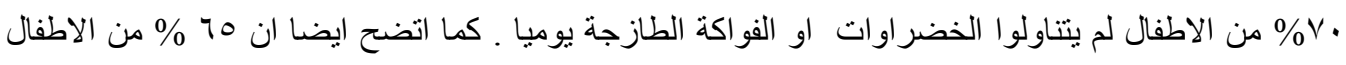

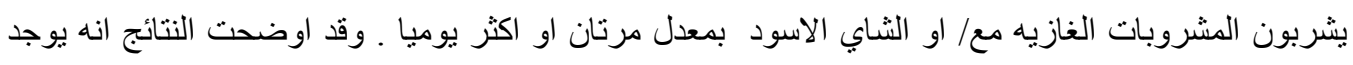

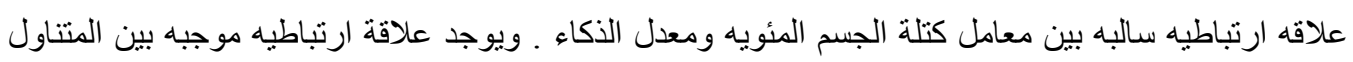

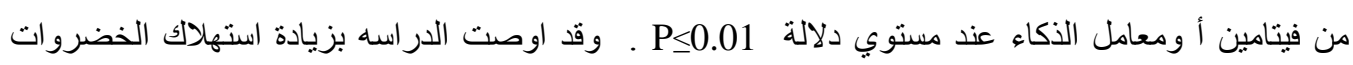

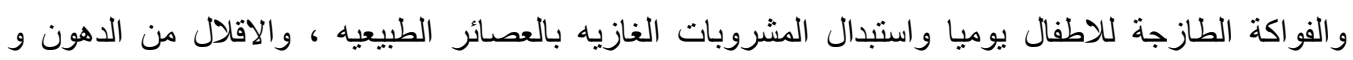
السكريات المضافة . 